\title{
Climate model based consensus on the hydrologic impacts of climate change to the Rio Lempa basin of Central America
}

\author{
E. P. Maurer ${ }^{1}$, J. C. Adam ${ }^{2}$, and A. W. Wood ${ }^{3}$ \\ ${ }^{1}$ Civil Engineering Department, Santa Clara University, Santa Clara, CA, USA \\ ${ }^{2}$ Department of Civil \& Environmental Engineering, Washington State University, Pullman WA, USA \\ ${ }^{3}$ Tier Group, Seattle, WA, USA
}

Received: 15 September 2008 - Published in Hydrol. Earth Syst. Sci. Discuss.: 14 November 2008

Revised: 2 February 2009 - Accepted: 2 February 2009 - Published: 18 February 2009

\begin{abstract}
Temperature and precipitation from 16 climate models each using two emissions scenarios (lower B1 and mid-high A2) were used to characterize the range of potential climate changes for the Rio Lempa basin of Central America during the middle (2040-2069) and end (2070-2099) of the 21 st century. A land surface model was applied to investigate the hydrologic impacts of these changes, focusing on inflow to two major hydropower reservoirs. By 20702099 the median warming relative to $1961-1990$ was $1.9^{\circ} \mathrm{C}$ and $3.4^{\circ} \mathrm{C}$ under $\mathrm{B} 1$ and $\mathrm{A} 2$ emissions, respectively. For the same periods, the models project median precipitation decreases of $5.0 \%$ (B1) and $10.4 \%$ (A2). Median changes by 2070-2099 in reservoir inflow were 13\% (B1) and 24\% (A2), with largest flow reductions during the rising limb of the seasonal hydrograph, from June through September. Frequency of low flow years increases, implying decreases in firm hydropower capacity of $33 \%$ to $53 \%$ by $2070-2099$.
\end{abstract}

\section{Introduction}

The intensification of the hydrological cycle anticipated as global warming continues will manifest itself distinctly in different regions (Stocker et al., 2001; Trenberth, 1999). This effect has already been observed as a global phenomenon, with generally increasing precipitation at mid- to high-latitudes and decreasing precipitation in the sub-tropics (Folland et al., 2001). Some regions are particularly vulnerable, including Central America, which Giorgi (2006) identified as a "hot-spot," the most prominent tropical area for

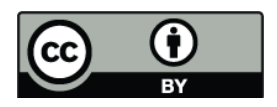

Correspondence to: E. P. Maurer (emaurer@engr.scu.edu) responsiveness to climate changes. This vulnerability has inspired recent studies that have found increases in Central American precipitation intensity (Aguilar et al., 2005), and examined climate model consensus of future drying projections (Christensen et al., 2007; Neelin et al., 2006; Rauscher et al., 2008).

The cumulative effects of warming and precipitation changes are integrated by watersheds to produce changes in intensity, duration, and frequency of both droughts and floods. A key region in Central America that is vulnerable to impacts of climate change is the Rio Lempa basin, the largest river system in Central America, with a drainage area covering over $18000 \mathrm{~km}^{2}$ (USACE, 1998). The Rio Lempa basin includes portions of three countries: El Salvador, Honduras, and Guatemala. The Rio Lempa is crucial for both water and energy services, as major hydroelectric facilities utilize Rio Lempa flow to generate electricity. Changes to hydropower due to climate change would constitute a severe impact, as nearly half of all electricity generated in El Salvador has historically originated from hydropower, and most of that from the Rio Lempa (USAID, 1994).

Past studies of hydrologic impacts of climate change on river basins have commonly included a single future climate projection, though some more recent efforts have included from four to six different global climate model (or general circulation model, GCM) projections of future climate (Wilby and Harris, 2006; Zierl and Bugmann, 2005). With the coordinated GCM output standardizing and archiving related to the IPCC Fourth Assessment studies (Meehl et al., 2005) the use of multi-model ensembles (using 10 or more GCMs) for climate change impact studies has become much more routine, including recent studies of hydrologic impacts (Christensen and Lettenmaier, 2007; Maurer, 2007; Maurer

Published by Copernicus Publications on behalf of the European Geosciences Union. 


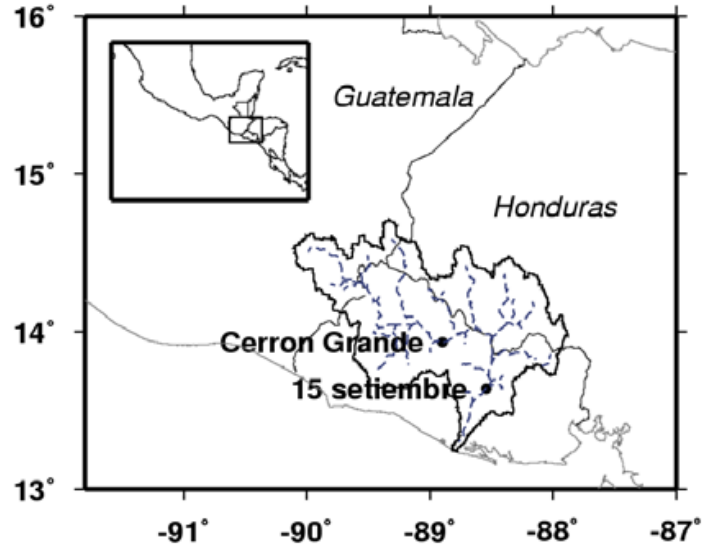

Fig. 1. Central America (inset) and the Rio Lempa basin. The two labelled points are dams with large reservoirs used for generating hydropower, discussed in the text.

and Duffy, 2005). The advantage of using many GCM projections of future climate is that the uncertainty in the projections, as represented by model consensus or spread, can be quantified.

In this study, we assess the hydrologic impacts of projected climate change on the Rio Lempa basin. We employ projections of $16 \mathrm{GCMs}$, each under a higher and lower greenhouse gas (GHG) emissions scenario. We address the following three questions: 1) What are the projected changes in precipitation and temperature for the Rio Lempa basin under higher and lower emissions scenarios? 2) What are the impacts on projected inflows to major reservoirs on the Rio Lempa? 3) Are the differences in impacts under different emissions scenarios statistically significant? This last question carries implications related to the degree to which the region will need to adapt to projected changes regardless of GHG mitigation efforts of countries responsible for recent and projected future warming.

\section{Study area}

The Rio Lempa basin, as in the region in general, experiences a wet season, generally from April through November, followed by a dry season. The rainy season is complicated by the precipitation distribution having a bimodal shape, with peaks in May-July and August-October, with an intervening dry period (Magaña et al., 1999; Taylor et al., 2002). An analysis of large scale climate model output over Central America identified a general drying trend, especially focused in the early rainy season during June and July (Rauscher et al., 2008), which would tend to decrease the bimodal nature of the rainy season. The Central America region and the Rio Lempa basin are depicted in Fig. 1.

\section{Methods}

The approach of this study is to begin with an ensemble of projected future climates through the 21 st century. The consensus among GCMs for the projected changes in precipitation and temperature are assessed for the Central America region. Each of 32 projected climates (16 GCMs each using two emissions scenarios) is used to drive a distributed land surface hydrology model, which produces an ensemble of projected streamflow at inflow points to major dams in the Rio Lempa system. Changes to the inflows are statistically analyzed to assess the confidence in various levels of projected changes in reservoir inflows. The majority of the approach follows Maurer (2007), though the application of the technique in Central America requires the use of a new, gridded global meteorological data set. Each step is described in greater detail below.

\subsection{Global climate model simulations}

For this study, simulations are used from the 16 GCMs (Table 1) that by November, 2006 had completed and archived at least one simulation each of the 20th century climate as well as future climate (through 2099) using two selected emissions scenarios. All data were obtained from the World Climate Research Programme's (WCRP's) Coupled Model Intercomparison Project phase 3 (CMIP3) multi-model dataset. The emissions scenarios used in this study, A2 and B1, are described in detail by Nakicenovic et al. (2000). Each scenario produces different atmospheric concentrations of future greenhouse gases. While $\mathrm{A} 2$ does not represent the highest $\mathrm{CO}_{2}$ emissions (at least through 2100) of the SRES scenarios (IPCC, 2001), and 21st century emissions to date appear to be above this projection (Raupach et al., 2007) it is the highest emission scenario for which most modeling groups have completed simulations, and represents the higher emission case in this study. B1 generally represents the best case of the SRES scenarios through the 21st century (Houghton et al., 2001). To facilitate analyzing multiple GCMs all output was interpolated onto a common $2^{\circ}$ grid prior to using the data.

Because the spatial scale of GCM output is too large to characterize climate over small areas like the Rio Lempa basin, some type of downscaling is necessary. The monthly precipitation and temperature output from each GCM was bias-corrected and statistically downscaled to a $1 / 2^{\circ}$ grid using an empirical statistical technique. The method, originally developed for adjusting GCM output for long-range streamflow forecasting (Wood et al., 2002) that was later adapted for use in studies examining the hydrologic impacts of climate change (Van Rheenen et al., 2004), maps the probability density functions for the monthly GCM precipitation and temperature onto those of gridded observed data for 1950 1999 , aggregated to the $2^{\circ}$ GCM scale. This same mapping is applied to the 21 st century GCM simulations. This 
Table 1. List of general circulation models used in this study.

\begin{tabular}{|c|c|c|c|}
\hline & Modeling Group, Country & IPCC Model I.D. & Primary Reference \\
\hline 1. & Bjerknes Centre for Climate Research & BCCR-BCM2.0 & (Furevik et al., 2003) \\
\hline 2. & Canadian Centre for Climate Modeling and Analysis & CGCM3.1 (T47) & (Flato and Boer, 2001) \\
\hline 3. & $\begin{array}{l}\text { Météo-France/Centre National de Recherches Météorologiques, } \\
\text { France }\end{array}$ & CNRM-CM3 & (Salas-Mélia et al., 2005) \\
\hline 4. & CSIRO Atmospheric Research, Australia & CSIRO-Mk3.0 & (Gordon et al., 2002) \\
\hline 5. & $\begin{array}{l}\text { US Dept. of Commerce/NOAA/Geophysical Fluid Dynamics Labo- } \\
\text { ratory, USA }\end{array}$ & GFDL-CM2.0 & (Delworth et al., 2006) \\
\hline 6. & $\begin{array}{l}\text { US Dept. of Commerce/NOAA/Geophysical Fluid Dynamics Labo- } \\
\text { ratory, USA }\end{array}$ & GFDL-CM2.1 & (Delworth et al., 2006) \\
\hline 7. & NASA/Goddard Institute for Space Studies, USA & GISS-ER & (Russell et al., 2000) \\
\hline 8. & Institute for Numerical Mathematics, Russia & INM-CM3.0 & (Diansky and Volodin, 2002) \\
\hline 9. & Institut Pierre Simon Laplace, France & IPSL-CM4 & (IPSL, 2005) \\
\hline 10. & $\begin{array}{l}\text { Center for Climate System Research (The University of Tokyo), Na- } \\
\text { tional Institute for Environmental Studies, and Frontier Research Cen- } \\
\text { ter for Global Change (JAMSTEC), Japan }\end{array}$ & MIROC3.2 (medres) & (K-1 model developers, 2004) \\
\hline 11. & $\begin{array}{l}\text { Meteorological Institute of the University of Bonn, Meteorological } \\
\text { Research Institute of KMA }\end{array}$ & ECHO-G & (Legutke and Voss, 1999) \\
\hline 12. & Max Planck Institute for Meteorology, Germany & ECHAM5/MPI-OM & (Jungclaus et al., 2006) \\
\hline 13. & Meteorological Research Institute, Japan & MRI-CGCM2.3.2 & (Yukimoto et al., 2001) \\
\hline 14. & National Center for Atmospheric Research, USA & PCM & (Washington et al., 2000) \\
\hline 15. & National Center for Atmospheric Research, USA & CCSM3 & (Collins et al., 2006) \\
\hline 16. & Hadley Centre for Climate Prediction and Research/Met Office, UK & UKMO-HadCM3 & (Gordon et al., 2000) \\
\hline
\end{tabular}

allows the mean and variability of each GCM to evolve in accordance with the simulation, while matching all statistical moments between the GCM and observations for 19501999. While the technique does not account for changes in the statistics of climate variability at scales less than monthly, it has compared favorably to different statistical and dynamic downscaling techniques (Wood et al., 2004) in the context of hydrologic impact studies. The downscaled data are used to force the land surface hydrology model to simulate the hydrologic response of the Rio Lempa system to the ensemble of future climate projections.

\subsection{Hydrology modeling}

The hydrologic model used in this study is the variable infiltration capacity (VIC) model (Liang et al., 1994). The VIC model is a distributed, physically-based hydrologic model that balances both surface energy and water budgets over a grid mesh, typically at resolutions ranging from a fraction of a degree to several degrees latitude by longitude. The VIC model uses a "mosaic" scheme that allows a statistical representation of the sub-grid spatial variability in topography, infiltration and vegetation/land cover, which is important when simulating hydrology in heterogeneous terrain. The resulting runoff at each grid cell is routed through a defined river system using the algorithm developed by Lohmann et al. (1996).

The VIC model has been successfully applied in many settings, from global to river basin scale (Maurer et al., 2001; Nijssen et al., 2001a; Nijssen et al., 1997), as well as in many studies of hydrologic impacts of climate change (Christensen et al., 2004; Hayhoe et al., 2004; Nijssen et al., 2001b; Payne et al., 2004). For this study, the model was run at a daily time step at a 1/2-degree resolution (measuring about $3000 \mathrm{~km}^{2}$ per grid cell) over the Rio Lempa. Elevation data for the basin is based on the 30-arc-second GLOBE dataset (Hastings and Dunbar, 1999). Land cover and soil hydraulic properties are the same as those used by Nijssen et al. (2001a), which utilized the Food and Agriculture Organization global soil database (FAO, 1995) with land cover based on the global land classification by Hansen et al. (2000). A river system was defined at a $1 / 8$ degree resolution, following the technique outlined by O'Donnell et al. (1999).

\subsection{Observed meteorology}

The base meteorological data consist of daily time-series for the period of 1950 through 1999 of precipitation, maximum temperature, minimum temperature, and wind speed. Data from a variety of sources (see Table 2) were compiled and gridded to a resolution of 1/2-degree over all global land areas. Monthly precipitation time-series were estimated by adjusting the Willmott and Matsuura (2001) precipitation for gauge undercatch, as described by Adam and Lettenmaier (2003). The adjustment in tropical areas is generally small $(<5 \%)$. Monthly time-series of maximum and minimum temperatures were created from a version of the New et al. (2000) dataset which has been updated to 2000 (Mitchell et al., 2004). To estimate the daily variability of 
Table 2. Data sources to create the 1/2-degree gridded global meteorological data for 1950 through 1999.

\begin{tabular}{|c|c|c|c|c|c|}
\hline Description & Reference & Variable & Time Step & Period of Use & Application \\
\hline $\begin{array}{l}\text { University of Delaware Cli- } \\
\text { mate Data }\end{array}$ & $\begin{array}{l}\text { Willmott and } \\
\text { Matsuura (2001) }\end{array}$ & Precipitation & Monthly Time Series & 1950-1999 & $\begin{array}{l}\text { To create monthly precipitation } \\
\text { variability }\end{array}$ \\
\hline $\begin{array}{l}\text { East Anglia Climatic Re- } \\
\text { search Unit Climate Data }\end{array}$ & $\begin{array}{l}\text { New et al. (2000) and } \\
\text { Mitchell et al. (2004) }\end{array}$ & Tmax and Tmin & Monthly Time Series & 1950-1999 & $\begin{array}{l}\text { To create monthly temperature } \\
\text { variability }\end{array}$ \\
\hline $\begin{array}{l}\text { University of Washington } \\
\text { Gauge Catch Corrections }\end{array}$ & $\begin{array}{l}\text { Adam and } \\
\text { Lettenmaier (2003) }\end{array}$ & Precipitation & Monthly Climatology & 1950-1999 & $\begin{array}{l}\text { To apply to the monthly precip- } \\
\text { itation time series to correct for } \\
\text { systematic bias }\end{array}$ \\
\hline $\begin{array}{l}\text { Princeton University cor- } \\
\text { rections to NCEP/NCAR } \\
\text { reanalysis }\end{array}$ & Sheffield et al. (2006) & Precipitation, Tmax, Tmin & Daily Time Series & 1950-1995 & $\begin{array}{l}\text { To create daily variability by } \\
\text { rescaling these data to match the } \\
\text { monthly variability of the above } \\
\text { time series }\end{array}$ \\
\hline $\begin{array}{l}\text { University of Washington } \\
\text { stochastically-generated } \\
\text { climate data }\end{array}$ & Nijssen et al. (2001a) & Precipitation, Tmax, Tmin & Daily Time Series & 1996-1999 & $\begin{array}{l}\text { To create daily variability by } \\
\text { rescaling these data to match the } \\
\text { monthly variability of the above } \\
\text { time series }\end{array}$ \\
\hline $\begin{array}{l}\text { NCEP/NCAR reanalysis } \\
\text { data }\end{array}$ & Kalnay et al. (1996) & Windspeed & Daily Time Series & 1950-1999 & $\begin{array}{l}\text { To create daily variability for } \\
\text { wind speed }\end{array}$ \\
\hline
\end{tabular}

precipitation, maximum and minimum temperature, 19501995 was constructed using Sheffield et al. (2006) and 19961999 was based on an updated, resampled version of Nijssen et al. (2001a). Daily 10-m wind speed was obtained from the NCEP-NCAR reanalysis project (Kalnay et al., 1996) and regridded to 1/2-degree resolution by linear interpolation.

While Table 2 describes the global dataset used, for this study we made one modification specific to our study domain. For the area over El Salvador, additional, finer resolution climatological precipitation data were available at a 5min spatial resolution (Centella et al., 1998), based on longterm averages at 46 stations. Since the global precipitation set mentioned above relied on a sparse network of observations over Central America, and since errors in precipitation can produce large errors in hydrologic simulations, the global data set was adjusted over El Salvador. For each month, the 1961-1990 average precipitation from Centella et al. was aggregated to 1/2-degree resolution, and an adjustment factor was computed for each 1/2-degree grid cell for each month to scale the global data set to match the Centella et al. 19611990 average.

\subsection{Assessing uncertainty}

Following the approach of Maurer (2007), results for each impact, in this case streamflow, for all GCMs are assembled for each emissions scenario. For each variable, the mean monthly value for each GCM for each of two defined periods is calculated, and these values for each GCM are combined by variable and period into ensembles. These ensembles of hydrologic variables are statistically analyzed using the non-parametric Mann-Whitney U test (Haan, 2002; Maurer, 2007), which tests for equality of means between two data sets. This test is used to determine the confidence level for the change from the climatological period (1961-1990) to different future 30 -year periods. In addition, the confi- dence with which it can be claimed that the two scenarios give different results is determined using the same test. Unless otherwise noted, all $\mathrm{p}$ values refer to results from the Mann-Whitney U test.

\section{Results and discussion}

For the observed period, the VIC model was forced with observed meteorology to assess its ability to reproduce historically observed reservoir inflows at the two points shown in Fig. 1. Then the 32 different future climate projections were used to drive the VIC model through the 21 st century, and the differences between reservoir inflows of the future and historical periods were assessed.

\subsection{Hydrology model calibration}

An automated calibration technique, using the MOCOM-UA software (Yapo et al., 1998), was employed to calibrate the VIC model at the two key locations on the Rio Lempa. There were two optimization criteria used in this study, both on monthly data: the Nash-Sutcliff model efficiency (Nash and Sutcliffe, 1970); and the mean absolute error. The NashSutcliff efficiency places higher emphasis on errors at high flows as compared to low flow periods, since it is based on the square of differences between simulated and observed flows (Krause et al., 2005). The mean absolute error provides a balance to this since it is based on absolute errors and is less dominated by a small number of large errors at high flows (Lettenmaier and Wood, 1993).

From the historical streamflow data available (beginning in 1957), one ten year period was selected with which to calibrate the VIC model for the two key locations used in this study. Due to the computational time involved in applying the automated calibration technique, including hundreds of hydrological simulations as the solution evolved toward 
its optimal parameter set, the length of the calibration period was chosen to be ten years: 1970-1979. Following the derivation of this optimal parameter set for the hydrologic model, the calibration was validated using a period of the same length: 1980-1989.

The results of the hydrologic model validation are shown in Fig. 2. A tendency to overestimate flows late in the wet season produces a moderate mean bias of $123 \mathrm{~m}^{3} / \mathrm{s}$ (or about $28.8 \%$ of the mean annual observed flow), but the correlation of simulated and monthly flow is relatively high, with a Pearson correlation coefficient of $r=0.85$. The difference in simulated and observed hydrographs is greatest during the two dry years, 1983 and 1986. It may be noted that 1983 began with a strong El Niño event, and another El Niño had formed by mid-1986. El Niño events have been connected to the intensification of the mid-summer drought in this region (Rauscher et al., 2008; Small et al., 2007). The calibration period of 1970-1979, without a comparably intense El Niño event to that of 1982-1983, may help explain why the hydrologic model does not capture these intensely dry periods as well as other years. However, validating the hydrologic model with a period that differs climatically from the calibration period is a stronger test for validity of the calibrated model, especially when applying the model to a future climate substantially different from the recent past.

The "observed" flows, which were produced by others based on estimated reservoir outflows and storage changes, are not directly comparable to the VIC hydrologic model output. These flow observations implicitly include the effects of upstream diversions, impoundments, and other anthropogenic effects (i.e., no adjustments have been made to the flow data to remove those effects present in the observations). The VIC model, by contrast, produces "natural" streamflows, as if there were no diversions or impoundments affecting the flow volume or timing. The Rio Lempa has been classified as being strongly affected by development, due to reservoir capacity and irrigation diversions (Nilsson et al., 2005). Consequently, it would be anticipated that the VIC simulated flows would overestimate the derived observed flows used in this study. These impacts would also be expected to be most intense during dry years, when impoundments would have a greater effect on streamflow and irrigation diversions would be expected to be proportionally greater. This would help explain some of the larger discrepancy between the modeled and observed flows during dry years.

Finally, in addition to calibration and observational issues there is additional uncertainty in the meteorology that was used to drive the VIC model. While we used the best available data to characterize precipitation over the basin, the network of precipitation stations is relatively sparse, and there are large temporal gaps in the records, which results in difficulty in capturing all of the variability in the basin (Centella et al., 1998).

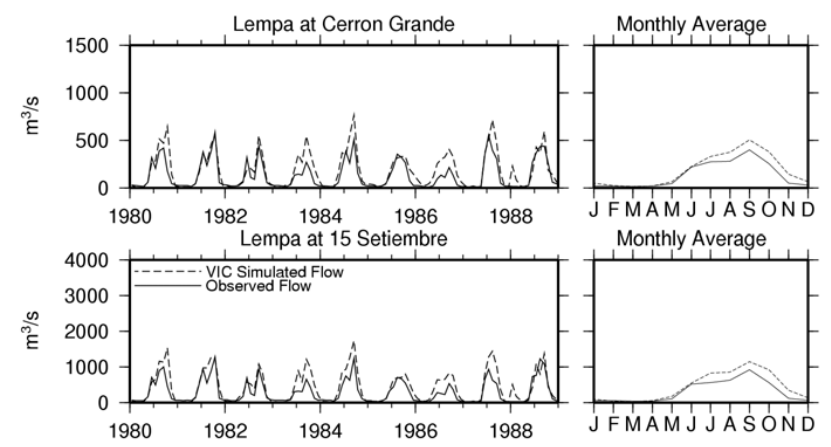

Fig. 2. Simulated and observed flow for the validation period at the two reservoir inflows considered in this study.

\subsection{Future climate projections for Central America}

The 32 projections are assembled into two ensembles, one for each emissions scenario. As is common in climate change impact studies with an ensemble of GCMs (Christensen and Lettenmaier, 2007; Maurer, 2007; Maurer and Duffy, 2005; Milly et al., 2002), we assume each of the GCMs produces an equally probable projection of future climate. While some studies of hydrologic impacts of climate change have examined skill-based weighting of future projections, the difference in outcomes from equal weighting has been found to be small (Dettinger, 2005; Wilby and Harris, 2006). A recent study (Brekke et al., 2008) investigated whether accounting for the ability of a GCM to capture hydrologically important climate features over California, United States would result in different future projections of future climate. It was found in that study that to characterize the range of potential future climate it was most important to include results from many GCMs, and that selecting only the "best" GCMs made only small differences in impact projections. This conclusion is supported in the present study, as our findings below are broadly consistent with those of Rauscher et al. (2008), who examine climate projections of Central America using only three GCMs, chosen for their fine spatial resolution and ability to replicate observed regional precipitation patterns.

Figure $3 \mathrm{a}$ and $\mathrm{b}$ show the projected changes in annual temperature and precipitation, respectively, between the historic (1961-1990) and future (2070-2099) periods for three quantiles (discussed below) of the ensemble of 16 GCM simulations for each emission scenario. This presents the context for regionally-projected changes, and the degree of consensus among GCMs. The median projection of temperature changes between these periods varies from $1-3^{\circ} \mathrm{C}$ under the $\mathrm{B} 1$ emissions scenario, and $2-4^{\circ} \mathrm{C}$ under the $\mathrm{A} 2$ emissions scenario. The greatest warming is focused generally to the North and West of El Salvador (Guatemala and Mexico). The $20 \%$ projections, which indicate $80 \%$ of GCMs projecting at least this level of warming, are $1-2^{\circ} \mathrm{C}$ for $\mathrm{B} 1$ and $2-4^{\circ} \mathrm{C}$ for A2. At the higher end $80 \%$ projections, for which $20 \%$ of 

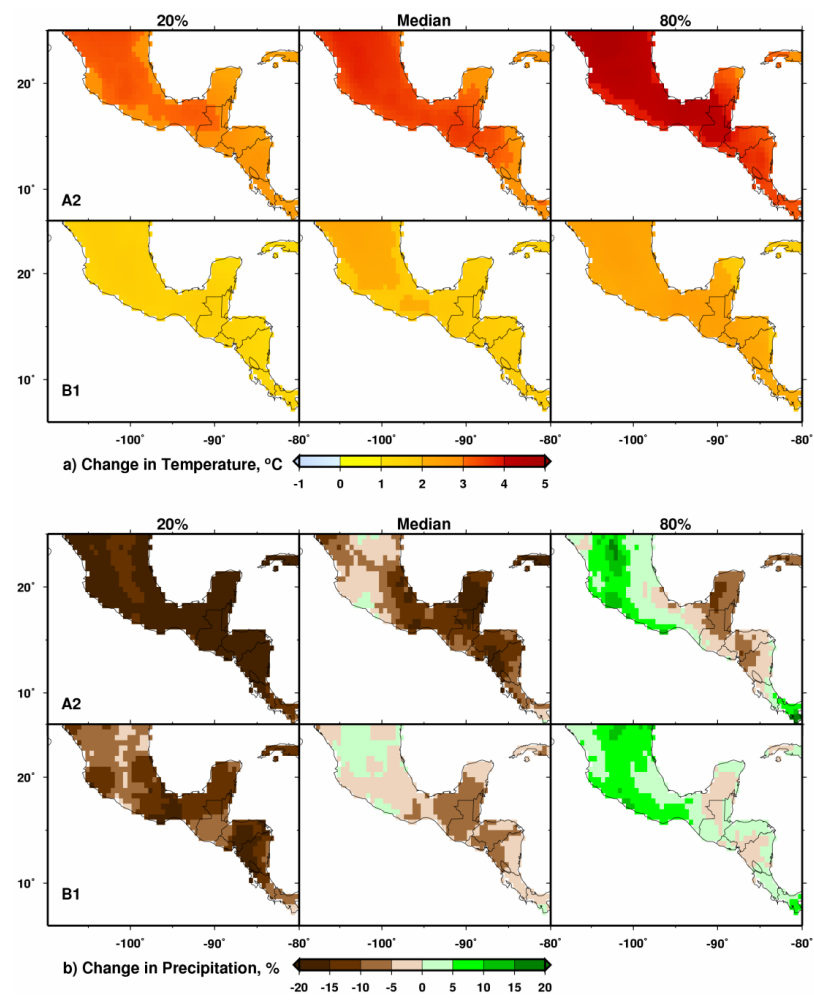

Fig. 3. (a) Projected annual temperature change and (b) precipitation change for Central America from 1961-1990 and 2070-2099 under higher (A2) emissions (upper row) and lower (B1) emissions (lower row). For the ensemble of 16 GCMs, 20, 50, and 80 percent non-exceedence values are shown in the three columns.

the GCMs exceed the level of warming shown, the warming for $\mathrm{B} 1$ is $2-3^{\circ} \mathrm{C}$, and for $\mathrm{A} 2$ is $3-5^{\circ} \mathrm{C}$. This illustrates a clear separation, by the end of the 21 st century, in the warming projected under the different emissions scenarios, both in terms of median and the range of projections by different GCMs.

The median precipitation projections for Central America in Fig. $3 \mathrm{~b}$ show drying trends, with reductions up to $20 \%$ in some areas. There is more severe drying under the higher A2 emissions scenario. For the $80 \%$ non-exceedence projections it is seen that $20 \%$ of the GCMs project increases in precipitation for roughly half of Central America under $\mathrm{A} 2$ emissions, and a greater proportion of the region for $\mathrm{B} 1$ emissions. However, even under this more optimistic (less dry) $80 \%$ end of the spectrum, El Salvador is projected generally to experience drying, especially under the higher A2 emissions.

\subsection{Climate Projections for the Rio Lempa}

Figure 4 shows the projected annual average changes for each of the 16 GCMs under each emissions scenario for the Rio Lempa basin. Temperature increases under the A2 emis-

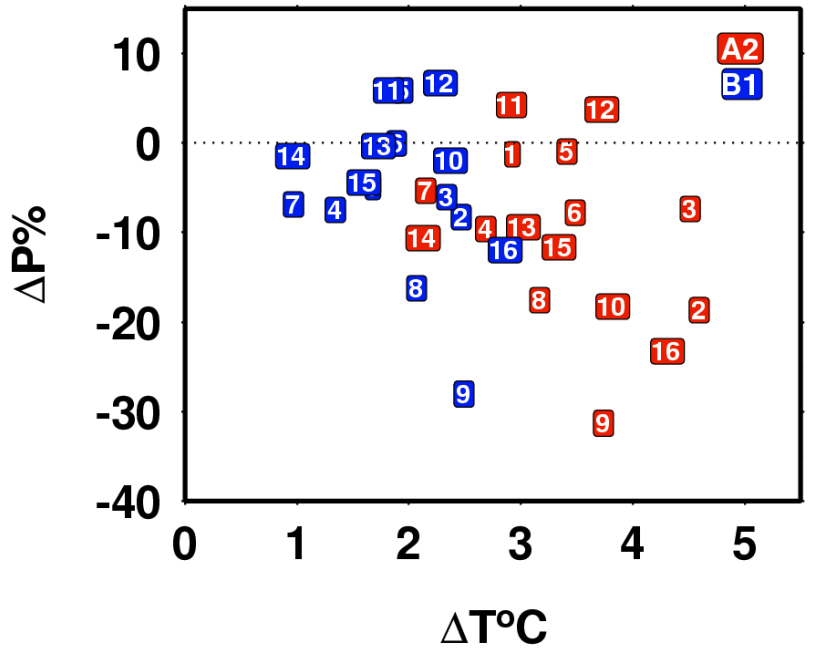

Fig. 4. Change in precipitation versus change in temperature for the 16 GCM projections under the two emissions scenarios for the Rio Lempa basin. Changes are between 1961-1990 and 2070-2099. Numbering refers to GCMs listed in Table 1.

sions scenario average $3.4^{\circ} \mathrm{C}$, and $1.9^{\circ} \mathrm{C}$ under $\mathrm{B} 1$, and this difference is highly statistically significant $(p<0.01)$. A drier future is most likely, with only 5 of the 32 GCM simulations showing slightly wetter futures (3-7\% wetter). The mean change in precipitation is $10.4 \%$ drier under $\mathrm{A} 2$ and $5.0 \%$ drier under B1. It is interesting to note that there is low statistical significance ( $p>0.15$ based on an ANOVA analysis for significance of linear slope) that temperature and precipitation changes are linearly related within either the B1 or A2 scenario. (Note that these results consider only the relationships among the two sets of $16 \mathrm{GCM}$ projections, and the correlation between precipitation and temperature within any GCM on a month-to-month basis is not evaluated.) This means that given an emissions scenario, there is not a strong tendency of GCMs projecting warmer futures to also project drier futures. However, there is a stronger tendency for the GCMs under the warmer A2 scenario to be drier than the B1 scenario $(p<0.10)$. This suggests that, since each GCM run represents one realization of climate response to specified GHG levels, that concurrent warming and drying is a GHG-driven phenomenon.

The seasonality of the changes in precipitation and temperature are non-uniform. Monthly projected precipitation changes, as a median of the GCM projections, are shown in Fig. 5. The precipitation decreases are focused on the early rainy season, May-August, with some lower magnitude wetter conditions projected in October-November. Precipitation changes are almost all highly significant, with the exception of September-November, where the GCM projections tend to disagree to a greater degree. For the A2 emissions scenario, precipitation changes grow progressively in magnitude through the 21 st century, whereas under the B1 emissions 


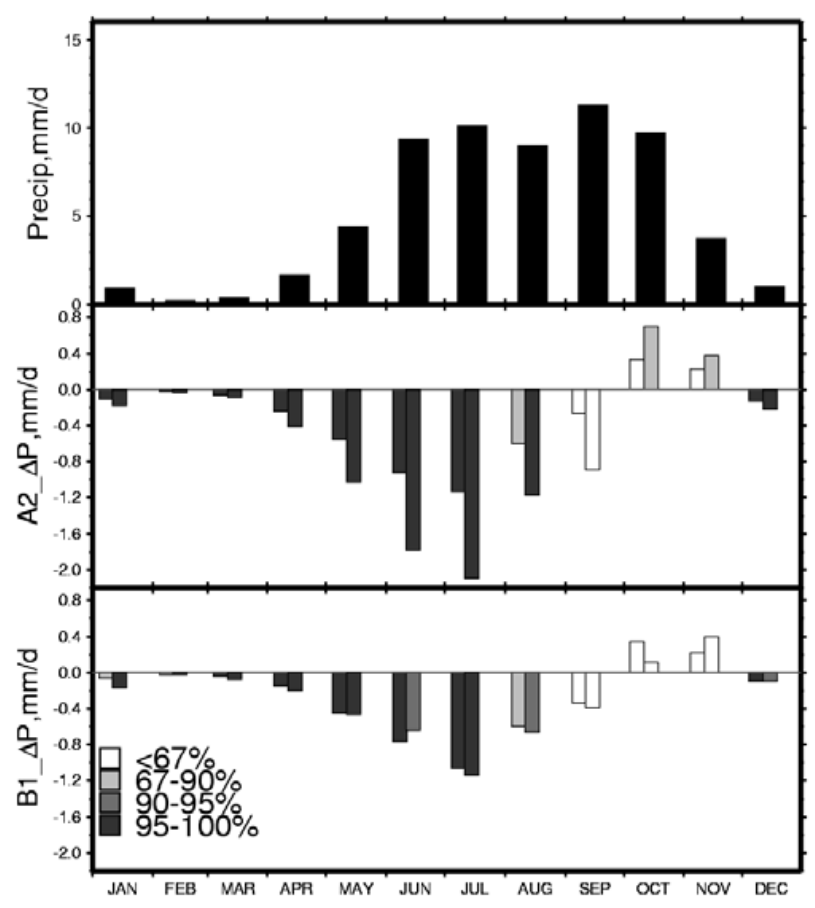

Fig. 5. Precipitation for the Rio Lempa basin. Top panel shows the climatological (1961-1990) monthly precipitation. The lower two panels show the median changes in precipitation projected by the GCMs under A2 emissions (center panel) and B1 (lower panel). Each month in the lower two panels shows two bars, which indicate the median changes from 1961-1990 for mid-21st century (20402069) and end of 21st century (2070-2099). Shading represents the confidence (1-p) that the projected change is statistically significant.

scenario, most 21 st century changes are expressed by 2040 2069, with diminishing further changes to end of century. By 2070-2099 the drying projected under A2 is significantly greater $(p<0.1)$ than under B1 for April-July, as well as on an annual average. Temperature increases (not shown), are $0.5-1.0^{\circ} \mathrm{C}$ greater in June-July compared to DecemberJanuary, thus the higher projected temperature changes occur during the early-mid rainy season when the greatest precipitation changes are also projected.

\subsection{Future hydrology of the Rio Lempa}

Figure 6 illustrates the impact of the projected climate changes on inflows to the downstream reservoir, 15 Setiembre (while not shown, the impacts at Cerron Grande were of different magnitude, but similar proportion). At Cerron Grande, under the B1 emissions scenario, annual average inflow (across the ensemble of GCMs) is projected to decline by $22 \mathrm{~m}^{3} / \mathrm{s}$ by $2040-2069$ and by $24 \mathrm{~m}^{3} / \mathrm{s}$ by $2070-2099$. Under the A2 scenario, the projected drop in annual average inflow is $25 \mathrm{~m}^{3} / \mathrm{s}$ by $2040-2069$ and $44 \mathrm{~m}^{3} / \mathrm{s}$ by $2070-2099$. At 15 Setiembre, annual average drop in inflow is $55 \mathrm{~m}^{3} / \mathrm{s}$ by $2040-2069$ and $60 \mathrm{~m}^{3} / \mathrm{s}$ by $2070-2099$ under B1, and

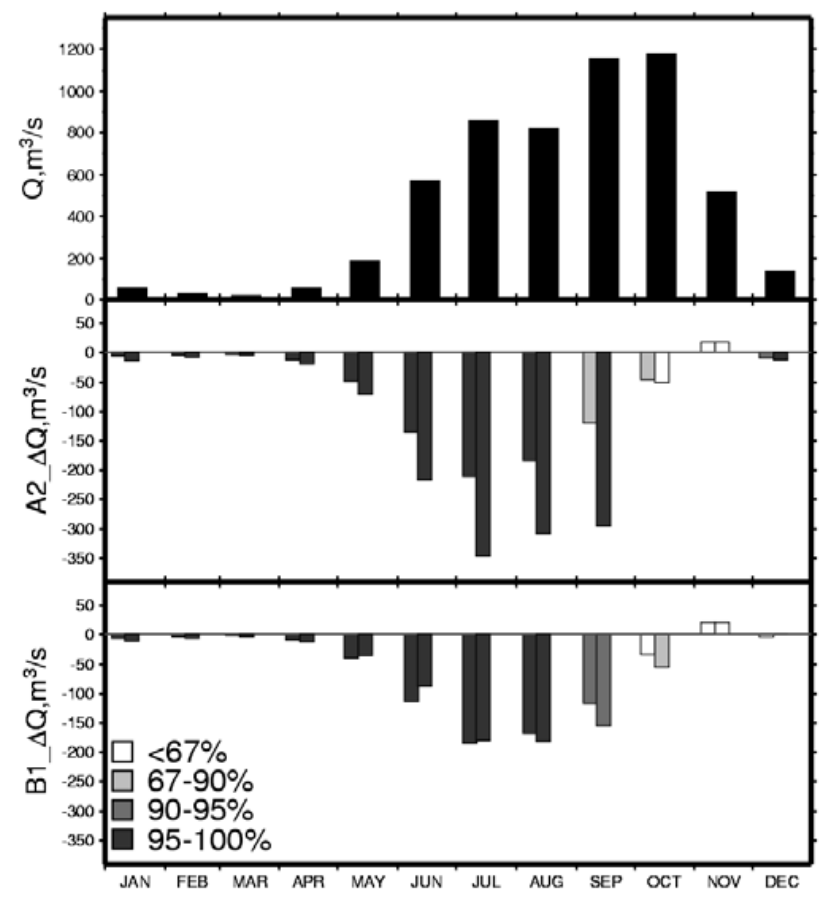

Fig. 6. Climatological (1961-1990) inflow at 15 Setiembre, and projected changes. Shading and symbols are identical to Fig. 5.

$64 \mathrm{~m}^{3} / \mathrm{s}$ by $2040-2069$ and $\mathrm{m}^{3} / \mathrm{s}$ by $2070-2099$ under A2. By the end of the century, these drops represent $13 \%$ (B1) and $24 \%$ (A2) of total annual inflows at both reservoirs. The greatest reduction in inflow for A2 emissions occurs in July (39\% at Cerron Grande and $41 \%$ at 15 Setiembre). Under B1 emissions the greatest drop in inflow occurs in August (21\% at Cerron Grande and $22 \%$ at 15 Setiembre).

All of the declines in reservoir inflows are statistically significant at very high confidence levels for January through August. Similar to precipitation projections, the GCM-based flow projections vary enough among GCMs for October and November that the confidence assigned to the changes is lower. With the exception of September-December (at Cerron Grande) and October-December (at 15 Setiembre), all of the differences by 2070-2099 are statistically different (at high confidence levels) between the A2 and B1 scenarios, showing distinctly different futures for the basin depending on future greenhouse gas emissions. This illustrates that the GCMs are in greater agreement regarding the changes through August, namely the projections for earlier onset and intensification of the mid-summer drought. After the midsummer drought, especially October-November the ensemble average projected changes in streamflow are smaller, both in absolute magnitude and relative to variability among GCM projections, as indicated in Fig. 6 by shorter bars and lower statistical confidence shown by lighter shading. A similar phenomenon was also observed in the more limited ensemble of Rauscher et al. (2008), who found that the pattern of 

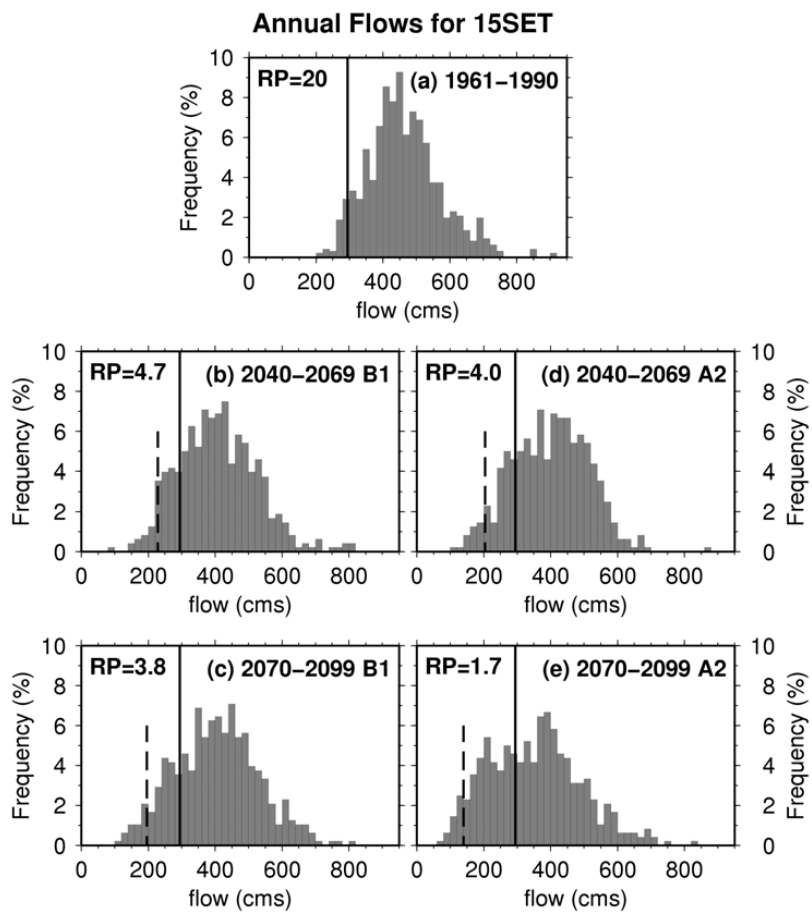

Fig. 7. Histograms of Annual Inflows in $\mathrm{m}^{3} / \mathrm{s}$ (cms) into 15 Setiembre for the 1961-1990 base period and two future periods. The solid vertical line indicates low flow with a return period (RP) of 20-years for 1961-1990, which is repeated on all panels. The vertical dashed lines in panels $b$ - $d$ indicate the $\mathrm{RP}=20$ value for each emissions scenario and future time period. The RP values in the upper left corner of panels b-d indicate the return period for flows occuring below the climatological $\mathrm{RP}=20$ value for 1961-1990.

a seasonal drop in sea-level pressure in April-May, correlated with early season rainfall, is projected to become less intense, while after the mid-summer in October-November the projection was for conditions similar to the late 20th century.

As noted above, for A2 emissions by 2070-2099, the median projection for the Rio Lempa basin was a $10.4 \%$ reduction in annual precipitation and a $3.4^{\circ} \mathrm{C}$ average temperature increase, which produced a $24 \%$ reduction in annual average flow. The phenomenon of precipitation changes having an amplified effect on runoff can be well understood from the notion that runoff is only a fraction of total precipitation. However, this can be complicated by the direct $\mathrm{CO}_{2}$ effects, which are the direct responses of vegetation to rising levels of $\mathrm{CO}_{2}$ (e.g., Wigley and Jones, 1985). Direct effects of $\mathrm{CO}_{2}$ on vegetation affect evapotranspiration (ET) by two counteracting dynamics: $\mathrm{CO}_{2}$-induced stomatal closure (which reduces ET); and photosynthesis stimulation (which increases leaf area index and ET) (Kergoat et al., 2002). In tropical regions, these two direct $\mathrm{CO}_{2}$ effects have been estimated to be of approximately equal magnitude, effectively canceling each other and leaving the net effect equal to that of warming alone (Levis et al., 2000), or leaving the direct $\mathrm{CO}_{2}$ contribution small relative to that due to changing climate (Piao et al., 2007). Thus, while we neglect direct effects of $\mathrm{CO}_{2}$ on vegetation, the results obtained here are plausibly representative of the sensitivity of the hydrologic system to climate change. An additional study with a biophysical model for this specific region could, however, be used to further investigate this hypothesis.

While future work will focus on the impacts on hydropower generation and possible adaptation approaches for the Rio Lempa, we begin that process here by examining low flow frequency, which for many hydropower systems is the determinant of firm power. Firm power is the energy a hydropower facility is able to supply in dry years, and in general, is the most economically-important characteristic of a hydropower installation. Figure 7 shows histograms of annual flows for 15 Setiembre (as with reservoir inflows, Cerron Grande shows a similar pattern). The 20 -year return period (RP) annual low flow, which in this case represents a low flow condition for which lower flows will only occur $5 \%$ of the time, is shown on each panel of the Figures. It is apparent that as flows decline through the 21 st century a greater proportion of years have average flow below that of the historic 20-year return period. The change in 20-year return flow drops by $22 \%$ to $31 \%$ (for B1 and A2, respectively) by 2040-2069 and 33\% to 53\% by 2070-2099 at both Cerron Grande and 15 Setiembre. As a preliminary estimate, even if reservoir levels could be maintained at historic levels, which is an optimistic assumption given the inflow reductions, the low flow decline would translate directly to reductions in firm power production. A notable consequence of this finding is that the amplification of precipitation changes to streamflow changes continues further when translated to impacts on hydropower.

\section{Conclusions}

As noted by the recent IPCC Working Group II report (IPCC, 2007), changes in temperatures and precipitation patterns will force many countries to adapt to inevitable changes in water supplies, and the effectiveness of adaptation efforts depends in part on the availability of general information on vulnerable areas and projected impacts. This study provides an assessment of potential changes, presented in a probabilistic framework, to the hydrology of the Rio Lempa, a key source of water and hydropower for El Salvador. The study incorporates climate projections by 16 GCMs each using both a lower and a mid-high emissions scenario, and uses these to drive a distributed hydrology model to estimate streamflow impacts.

We find that by the end of the 21 st century for the Rio Lempa basin:

- Average temperatures will rise from $1.9-3.4^{\circ} \mathrm{C}$, with the greatest increase in June-July. 
- The consensus of GCMs indicates a drier future, with an overall reduction in precipitation of 5 to $10 \%$.

- The majority of the drop in precipitation will occur in May-July, corresponding to the first half of the rainy season.

- Inflows to the major reservoirs will decline on average by 13 to $24 \%$.

- Peak declines in reservoir inflow will occur in JulyAugust, and range from 21 to $41 \%$.

- Decreases in firm hydropower generation capability, estimated in a preliminary manner, may range from $33 \%$ to $53 \%$ near the end of the 21 st century.

In all cases, the most severe impacts occur under the higher emissions A2 scenario, and are roughly a factor of two greater than the impacts under the lower B1 emissions scenario. The implications of these projections are two-fold: water management agencies in the region should prepare for reductions in reservoir inflow of at least $13 \%$ over the coming decades; and if the major GHG-producing countries are unsuccessful in dramatically reducing emissions of greenhouse gases, water managers should prepare for much greater flow reductions.

Acknowledgements. We are indebted to Jacqueline Cativo and Ismael Sánchez of the Departamento de Ciencias Energéticas y Fluídicas at the Universidad Centroamericana in San Salvador for their support and assistance in this study. We are grateful to Mauricio Martinez of the Servicio Nacional de Estudios Territoriales (SNET), San Salvador, El Salvador, and Rodolfo Cáceres of the Comisión Ejecutíva Hidroelectrica del Rio Lempa (CEL) for generously sharing their time and helping to acquire the data essential to this study. The first author received the generous support of an Arthur Vining Davis grant through Santa Clara University. We acknowledge the modeling groups for making their simulations available for analysis, the Program for Climate Model Diagnosis and Intercomparison (PCMDI) for collecting and archiving the CMIP3 model output, and the WCRP's Working Group on Coupled Modeling (WGCM) for organizing the model data analysis activity. The WCRP CMIP3 multi-model dataset is supported by the Office of Science, U.S. Department of Energy. We are grateful for the thorough review and helpful comments of two anonymous reviewers who helped improve this manuscript.

Edited by: B. van den Hurk

\section{References}

Adam, J. C. and Lettenmaier, D. P.: Adjustment of global gridded precipitation for systematic bias, J. Geophys. Res., 108, 1-14, 2003.

Aguilar, E., Peterson, T. C., Ramirez Obando, P., Frutos, R., Retana, J. A., Solera, M., Soley, J., Gonzalez Garcia, I., Araujo, R. M., Rosa Santos, A., Valle, V. E., Brunet, M., Aguilar, L.,
Alvarez, L., Bautista, M., Castañon, C., Herrera, L., Ruano, E., Sinay, J. J., Sanchez, E., Hernandez Oviedo, G. I., Obed, F., Salgado, J. E., Vazquez, J. L., Baca, M., Gutierrez, M., Centella, C., Espinosa, J., Martinez, D., Olmedo, B., Ojeda Espinoza, , C. E., Nuñez, R., Haylock, M., Benavides, H., and Mayorga, R.: Changes in precipitation and temperature extremes in Central America and northern South America, 1961-2003, J. Geophys. Res., 110, D23107, doi:10.1029/2005JD006119, 2005.

Brekke, L. D., Dettinger, M. D., Maurer, E. P., and Anderson, M.: Significance of model credibility in estimating climate projection distributions for regional hydroclimatological risk assessments, Clim. Change, 89, 371-394, doi: 10.1007/s10584-007-9388-3, 2008.

Centella, A., Castillo, L., and Aguilar, A.: Escenarios climáticos de referencia para la República de El Salvador. Programa de las Naciones Unidas para el Desarrollo, San Salvador, El Salvador 21 pp. 1998.

Christensen, J. H., Hewitson, B., Busuioc, A., Chen, A., Gao, X., Held, I., Jones, R., Kolli, R. K., Kwon, W.-T., Laprise, R., Magaña Rueda, V., Mearns, L., Menéndez, C. G., Räisänen, J., Rinke, A., Sarr, A., and Whetton, P.: Regional climate projections. Climate Change 2007: The Physical Science Basis. Contribution of Working Group I to the Fourth Assessment Report of the Intergovernmental Panel on Climate Change, edited by: Solomon, S., Qin, D., Manning, M., Chen, Z., Marquis, M., Averyt, K. B., Tignor, M., and Miller, H. L., Eds., Cambridge University Press, 2007.

Christensen, N. S. and Lettenmaier, D. P.: A multimodel ensemble approach to assessment of climate change impacts on the hydrology and water resources of the Colorado River Basin, Hydrol. Earth Syst. Sci., 11, 1417-1434, 2007, http://www.hydrol-earth-syst-sci.net/11/1417/2007/.

Christensen, N. S., Wood, A. W., Voisin, N., Lettenmaier, D. P., and Palmer, R. N.: The effects of climate change on the hydrology and water resources of the Colorado River basin, Clim. Change, 62, 337-363, 2004.

Collins, W. D., Bitz, C. M., Blackmon, M. L., Bonan, G. B., Bretherton, C. S., Carton, J. A., Chang, P., Doney, S. C., Hack, J. J., Henderson, T. B., Kiehl, J. T., Large, W. G., McKenna, D. S., Santer, B. D., and Smith, R. D.: The Community Climate System Model: CCSM3, J. Climate, 19, 2122-2143, 2006.

Delworth, T. L., Broccoli, A. J., Rosati, A., Stouffer, R. J., Balaji, V., Beesley, J. A., Cooke, W. F., Dixon, K. W., Dunne, J., Dunne, K. A., Durachta, J. W., Findell, K. L., Ginoux, P., Gnanadesikan, A., Gordon, C. T., Griffies, S. M., Gudgel, R, Harrison, M. J., Held, I. M., Hemler, R. S., Horowitz, L. W., Klein, S. A., Knutson, T. R., Kushner, P. J., Langenhorst, A. R., Lee, H.-C., Lin, S.-J, Lu, J., Malyshev, S. L., Milly, P. C. D., Ramaswamy, V., Russell, J., Schwarzkopf, M. D., Shevliakova, E., Sirutis, J. J., Spelman, M. J., Stern, W. F., Winton, M., Wittenberg, A. T., Wyman, B., Zeng, F., and Zhang, R.: GFDL's CM2 global coupled climate models - Part 1: Formulation and simulation characteristics, J. Climate, 19, 643-674, 2006.

Dettinger, M. D.: From climate-change spaghetti to climate-change distributions for 21 st century California, San Francisco Estuary \& Watershed Science, 3, 1-14, 2005.

Diansky, N. A. and Volodin, E. M.: Simulation of present-day climate with a coupled Atmosphere-ocean general circulation model, Izv. Atmos. Ocean. Phys. (Engl. Transl.), 38, 732-747, 
2002.

FAO: The digital soil map of the world, Version 3.5. United Nations Food and Agriculture Organization, Rome, Italy, 1995.

Flato, G. M. and Boer, G. J.: Warming asymmetry in climate change simulations, Geophys. Res. Lett., 28, 195-198, 2001.

Folland, C. K., Karl, T. R., Christy, J. R., Clarke, R. A., Gruza, G. V., Jouzel, J, Mann, M. E., Oerlemans, J., Salinger, M. J., and Wang, S.-W.: Observed Climate Variability and Change. Climate Change 2001: The Scientific Basis, edited by: Houghton, J. T., Ding, Y., Griggs, D. J., Noguer, M., van der Linden, P. J., and Xiaosu, D., Cambridge University Press, 99-181, 2001.

Furevik, T., Bentsen, M., Drange, H., Kindem, I. K. T., and Kvamstø, N. G.: Description and evaluation of the bergen climate model: ARPEGE coupled with MICOM, Clim. Dynam., 21, 27-51, 2003.

Giorgi, F.: Climate change hot-spots, Geophys. Res. Lett., 33, L08707, doi:10.1029/2006GL025734, 2006.

Gordon, C., Cooper, C., Senior, C. A., Banks, H., Gregory, J. M., Johns, T. C., Mitchell, J. F. B., and Wood, R. A.: The simulation of SST, sea ice extents and ocean heat transports in a version of the Hadley Centre coupled model without flux adjustments, Clim. Dynam., 16, 147-168, 2000.

Gordon, H. B., Rotstayn, L. D., McGregor, J. L., Dix, M. R., Kowalczyk, E. A., O'Farrell, S. P., Waterman, L. J., Hirst, A. C., Wilson, S. G., Collier, M. A., Watterson, I. G., and Elliott, T. I.: The CSIRO Mk3 climate system model, CSIRO Atmospheric Research Technical Paper No.60. CSIRO. Division of Atmospheric Research, 130 pp., 2002.

Haan, C. T.: Statistical Methods in Hydrology, second edition. Iowa State Press, 496 pp., 2002.

Hansen, M. C., DeFries, R. S., Townshend, J. R. G., and Sohlberg, R.: Global land cover classification at $1 \mathrm{~km}$ spatial resolution using a classification tree approach, International Journal of Remote Sensing, 21, 1331-1364, 2000.

Hastings, D. A. and Dunbar, P. K.: Global land one-kilometer base elevation (GLOBE) digital elevation model, documentation, volume 1.0. National Oceanic and Atmospheric Administration, National Geophysical Data Center, Boulder, CO, USA. 1999.

Hayhoe, K., D. Cayan, Field, C. B., Frumhoff, P. C., Maurer, E. P., Miller, N. L, Moser, S. C., Schneider, S. H., Cahill, K. N., Cleland, E. E., Dale, L., Drapek, R., Hanemann, R. M., Kalkstein, L. S., Lenihan, J., Lunch, C. K., Neilson, R. P, Sheridan, S. C., and Verville, J. H.: Emissions pathways, climate change, and impacts on California, Proceedings of the National Academy of Sciences, 101, 12422-12427, 2004.

Houghton, J. T., Ding, Y., Griggs, D. J., Noguer, M., van der Linden, P. J., and Xiaosu, D.: Climate Change 2001: The scientific basis. contribution of Working Group I to the third assessment report of the Intergovernmental Panel on Climate Change. Cambridge University Press, 881 pp., 2001.

IPCC: Climate change 2007: impacts, adaptation and vulnerability, working group II contribution to the Intergovernmental Panel on Climate Change Fourth Assessment Report. Intergovernmental Panel on Climate Change, Geneva, Switzerland 23 pp., 2007.

IPSL: The new IPSL climate system model: IPSL-CM4. Institut Pierre Simon Laplace des Sciences de l'Environnement Global, Paris, France 73 pp., 2005.

Jungclaus, J. H., Botzet, M., Haak, H., Keenlyside, N., Luo, J.J., Latif, M., Marotzke, J, Mikolajewicz, U., and Roeckner,
E.: Ocean circulation and tropical variability in the AOGCM ECHAM5/MPI-OM, Journal of Climate, 19, 3952-3972, 2006.

K-1 model developers: K-1 coupled model (MIROC) description', K-1 technical report, 1. Center for Climate System Research, University of Tokyo, Tokyo, Japan 34 pp., 2004.

Kalnay, E., Kanamitsu, M., Kistler, R., Collins, W., Deaven, D., Gandin, L., Iredell, M., Saha, S., White, G., Woollen, J., Zhu, Y., Leetmaa, A., and Reynolds, B.: The NCEP/NCAR 40-year reanalysis project, Bulletin of the American Meteorological Society, 77, 437-472, 1996.

Kergoat, L., Lafont, S., Douville, H., Berthelot, B., Dedieu, G., Planton, S., and Royer, J.-F.: Impact of doubled $\mathrm{CO}_{2}$ on globalscale leaf area index and evapotranspiration: Conflicting stomatal conductance and LAI responses, J. Geophys. Res., 107, 4808, doi:10.1029/2001JD001245, 2002.

Krause, P., Boyle, D. P., and Bäse, F.: Comparison of different efficiency criteria for hydrological model assessment, Adv. Geosci., 5, 89-97, 2005.

Legutke, S. and Voss, R.: The Hamburg atmosphere-ocean coupled circulation model ECHO-G, Technical report, No. 18. German Climate Computer Centre (DKRZ), Hamburg, Germany 62 pp., 1999.

Lettenmaier, D. P. and Wood, E. F.: Hydrologic Forecasting. Handbook of Hydrology, D. R. Maidment, Ed., McGraw-Hill Inc., 26.1-26.30, 1993.

Levis, S., Foley, J. A., and Pollard, D.: Large-scale vegetation feedbacks on a doubled- $\mathrm{CO}_{2}$ climate, Journal of Climate, 13, 13131325, 2000.

Liang, X., Lettenmaier, D. P., Wood, E., and Burges, S. J.: A simple hydrologically based model of land surface water and energy fluxes for general circulation models, Journal of Geophysical Research, 99, 14415-14428, 1994.

Lohmann, D., Nolte-Holube, R., and Raschke, E.: A large-scale horizontal routing model to be coupled to land surface parameterization schemes, Tellus, 48A, 708-721, 1996.

Magaña, V., Amador, J. A., and Medina, S.: The midsummer drought over Mexico and Central America, J. Climate, 12, 1577 1588, 1999.

Maurer, E. P.: Uncertainty in hydrologic impacts of climate change in the Sierra Nevada, California under two emissions scenarios, Clim. Change, 82, 309-325, doi:10.1007/s10584-006-91809, 2007.

Maurer, E. P. and Duffy, P. B.: Uncertainty in projections of streamflow changes due to climate change in California, Geophys. Res. Lett., 32, L03704, doi:10.1029/2004GL021462, 2005.

Maurer, E. P., O’Donnell, G. M., Lettenmaier, D. P., and Roads, J. O.: Evaluation of the land surface water budget in NCEP/NCAR and NCEP/DOE reanalyses using an off-line hydrologic model, J. Geophys. Res., 106, 17841-17862, 2001.

Meehl, G. A., Covey, C., McAvaney, B., Latif, M., and Stouffer, R. J.: Overview of the Coupled Model Intercomparison Project, B. Am. Meteor. Soc., 86, 89-93, 2005.

Milly, P. C. D., Wetherald, R. T., Dunne, K. A., and Delworth, T. L.: Increasing risk of great floods in a changing climate, Nature, 415, 514-517, 2002.

Mitchell, T. D., Carter, T. R., Jones, P. D., Hulme, M., and New, M. G.: A comprehensive set of high-resolution grids of monthly climate for Europe and the globe: the observed record (19012000) and 16 scenarios (2001-2100). Tyndall Centre for Climate 
Change Research, University of East Anglia, Norwich, UK 30 pp., 2004.

Nakicenovic, N., Alcamo, J., Davis, G., de Vries, B., Fenhann, J., Gaffin, S., Gregory, K, Grübler, A., Yong Jung, T., Kram, T., Lebre La Rovere, E., Michaelis, L., Mori, S., Morita, T., Pepper, W., Pitcher, H., Price, L., Riahi, K., Roehrl, A., Rogner, H.-H., Sankovski, A., Schlesinger, M., Shukla, P., Smith, S., Swart, R, van Rooijen, S., Victor, N., and Dadi, Z.: Special report on emissions scenarios. Cambridge U. Press, 570 pp., 2000.

Nash, J. E. and Sutcliffe, J. V.: River flow forecasting through conceptual models part I - A discussion of principles, J. Hydrology, 10, 282-290, 1970.

Neelin, J. D., Münnich, M., Su, H., Meyerson, J. E., and Holloway, C. E.: Tropical drying trends in global warming models and observations, Proceedings National Academy of Sciences, 103, 6110-6115, 2006.

New, M. G., Hulme, M., and Jones, P. D.: Representing twentiethcentury space-time climate variability. Part II: development of 1961-1990 monthly grids of terrestrial surface climate, J. Climate, 12, 829-856, 2000.

Nijssen, B., Schnur, R., and Lettenmaier, D. P.: Global retrospective estimation of soil moisture using the VIC land surface model, 1980-1993, J. Climate, 14, 1790-1808, 2001a.

Nijssen, B., O'Donnell, G. M., Hamlet, A. F., and Lettenmaier, D. P.: Hydrologic sensitivity of global rivers to climate change, Clim. Change, 50, 143-175, 2001b.

Nijssen, B., Lettenmaier, D. P., Liang, X., Wetzel, S. W., and Wood, E.: Streamflow simulation for continental-scale basins, Water Resources Research, 33, 711-724, 1997.

Nilsson, C., Reidy, C. A., Dynesius, M., and Revenga, C.: Fragmentation and flow regulation of the world's large river systems, Science, 308, 405-408, 2005.

O'Donnell, G., Nijssen, B., and Lettenmaier, D. P.: A simple algorithm for generating streamflow networks for grid-based, macroscale hydrological models, Hydrological Processes, 13, 1269-1275, 1999.

Payne, J. T., Wood, A. W., Hamlet, A. F., Palmer, R. N., and Lettenmaier, D. P.: Mitigating the effects of climate change on the water resources of the Columbia River Basin, Clim. Change, 62, 233-256, 2004.

Piao, S., Friedlingstein, P., Ciais, P., de Noblet-Ducoudre, N., Labat, D., and Zaehle, S.: Changes in climate and land use have a larger direct impact than rising $\mathrm{CO}_{2}$ on global river runoff trends, Proceedings of the National Academy of Sciences, 104, 1524215247, 2007.

Raupach, M. R., Marland, G., Ciais, P., LeQuere, C., Canadell, J. G., and Field, C. B.: Global and regional drivers of accelerating $\mathrm{CO}_{2}$ emissions, Proceedings National Academy of Sciences, 104, 10288-10293, doi:10.1073/pnas.0700609104, 2007.

Rauscher, S. A., Giorgi, F., Diffenbaugh, N. S., and Seth, A.: Extension and intensification of the Meso-American mid-summer drought in the twenty-first century, Clim. Dynam., 31, 551-571, doi:10.1007/s00382-007-0359-1, 2008.

Russell, G. L., Miller, J. R., Rind, D., Ruedy, R. A., Schmidt, G. A., and Sheth, S.: Comparison of model and observed regional temperature changes during the past 40 years, J. Geophys. Res.Atmos., 105, 14891-14898, 2000.

Salas-Mélia, D., F. Chauvin, Déqué, M., Douville, H., Gueremy, J. F., Marquet, P., Planton, S., Royer, J. F., and Tyteca, S.:
Description and validation of the CNRM-CM3 global coupled model, CNRM working note 103. Centre National de Recherches Météorologiques, Météo-France, Toulouse, France 36 pp., 2005.

Sheffield, J., Goteti, G., and Wood, E. F.: Development of a 50yr high-resolution global dataset of meteorological forcings for land surface modeling, J. Clim., 19, 3088-3111, 2006.

Small, R. J. O., de Szoeke, S. P., and Xie, S.-P.: The Central American midsummer drought: regional aspects and large-scale forcing, J. Clim., 20, 4853-4873, doi:101175/JCLI4261.1, 2007.

Stocker, T. F., Clarke, G. K. C., Le Treut, H., Lindzen, R. S., Meleshko, V. P., Mugara, R. K., Palmer, T. N., Pierrehumbert, R. T., Sellers, P. J., Trenberth, K. E., and Willebrand, J.: Physical climate processes and feedbacks. Climate Change 2001: The Scientific Basis, edited by: Houghton, J. T., Ding, Y., Griggs, D. J., Noguer, M., van der Linden, P. J., and Xiaosu, D.,= Cambridge University Press, 417-470, 2001.

Taylor, M. A., Enfield, D. B., and Chen, A. A.: Influence of Tropical Atlantic versus the tropical Pacific on Caribbean rainfall, J. Geophys. Res., 107, 3127, doi:10.1029/2001JC001097, 2002.

Trenberth, K. E.: Conceptual framework for changes of extremes of the hydrological cycle with climate change, Clim. Change, 42, 327-339, 1999.

USACE: Water resources assessment of El Salvador. United States Army Corps of Engineers, Mobile District \& Topographic Engineering Center, Mobile, AL 71 pp. 1998.

USAID: Energy from sugarcane cogeneration in el Salvador, United States Agency for International Development, Office of Energy, Environment, and Technology Bureau for Global Programs, Field Support, and Research, Washington, D.C. 79 pp., 1994.

Van Rheenen, N. T., Wood, A. W., Palmer, R. N., and Lettenmaier, D. P.: Potential implications of PCM climate change scenarios for Sacramento-San Joaquin River Basin hydrology and water resources, Clim. Change, 62, 257-281, 2004.

Washington, W. M., Weatherly, J. W., Meehl, G. A., Semtner, A. J., Bettge, T. W., Craig, A. P., Strand, W. G., Arblaster, J., Wayland, V. B., James, R., and Zhang, Y.: Parallel climate model (PCM) control and transient simulations, Clim. Dynam., 16, 755-774, 2000.

Wigley, T. M. L. and Jones, P. D.: Influences of precipitation changes and direct $\mathrm{CO}_{2}$ effects on streamflow, Nature, 314, 149 $152,1985$.

Wilby, R. L. and Harris, I.: A framework for assessing uncertainties in climate change impacts: low-flow scenarios for the River Thames, UK, Water Resour. Res., 42, W02419, doi:10.1029/2005WR004065, 2006.

Willmott, C. J. and Matsuura, K.: Terrestrial air temperature and precipitation: monthly and annual time series (1950-1999) (Version 1.02). Center for Climatic Research, University of Delaware, Newark, DE, USA. 2001.

Wood, A. W., Maurer, E. P., Kumar, A., and Lettenmaier, D. P.: Long-range experimental hydrologic forecasting for the eastern United States, J. Geophys. Res.-Atmos., 107, 4429, doi:10.1029/2001JD000659, 2002.

Wood, A. W., Leung, L. R., Sridhar, V., and Lettenmaier, D. P.: Hydrologic implications of dynamical and statistical approaches to downscaling climate model outputs, Clim. Change, 62, 189216, 2004.

Yapo, P. O., Gupta, H. V., and Sorooshian, S.: Multi-objective global optimization for hydrologic models, J. Hydrol., 204, 83- 
97, 1998.

Yukimoto, S., Noda, A., Kitoh, A., Sugi, M., Kitamura, Y., Hosaka, M., Shibata, K., Maeda, S., and Uchiyama, T.: The new Meteorological Research Institute coupled GCM (MRI-CGCM2), Model climate and variability, Papers in Meteorology and Geophysics, 51, 47-88, 2001.
Zierl, B. and Bugmann, H.: Global change impacts on hydrological processes in Alpine catchments, Water Resour. Res., 41, W02028, doi:10.1029/2004WR003447, 2005. 